\title{
Role of IgM and IgA Antibodies in the Neutralization of SARS-CoV-2
}

Jéromine Klingler ${ }^{1,2}$, Svenja Weiss ${ }^{1,2}$, Vincenza Itri $^{1}$, Xiaomei Liu ${ }^{1,2}$, Kasopefoluwa Y. Oguntuyo ${ }^{3}$,

5 Christian Stevens ${ }^{3}$, Satoshi Ikegame ${ }^{3}$, Chuan-Tien Hung ${ }^{3}$, Gospel Enyindah-Asonye ${ }^{1}$, Fatima Amanat ${ }^{3,4}$,

6 Ian Baine $^{5}$, Suzanne Arinsburg ${ }^{5}$, Juan C. Bandres ${ }^{2}$, Erna Milunka Kojic ${ }^{6}$, Jonathan Stoever ${ }^{7}$, Denise

7 Jurczyszak ${ }^{3,4}$, Maria Bermudez-Gonzalez ${ }^{3}$, Arthur Nádas $^{8}$, Sean Liu ${ }^{1,3}$, Benhur Lee ${ }^{3}$, Susan Zolla-

8 Pazner $^{1,3^{*}}$, Catarina E. Hioe ${ }^{1,2,3^{*}}$

$9{ }^{1}$ Division of Infectious Diseases, Department of Medicine, Icahn School of Medicine at Mount Sinai, New

10 York, NY USA.

11 2James J. Peters VA Medical Center, Bronx, NY, USA.

$12{ }^{3}$ Department of Microbiology, Icahn School of Medicine at Mount Sinai, New York, NY, USA.

$13{ }^{4}$ Graduate School of Biomedical Sciences, Icahn School of Medicine at Mount Sinai, New York, NY, 14 USA.

$15{ }^{5}$ Department of Pathology, Icahn School of Medicine at Mount Sinai, New York, NY, USA.

$16{ }^{6}$ Division of Infectious Diseases, Department of Medicine, Mount Sinai West and Morningside, NY, USA.

$17 \quad{ }^{7}$ Pulmonary and Critical Care Medicine, Mount Sinai West, NY, USA.

$18{ }^{8}$ Department of Environment Medicine, NYU School of Medicine, New York, NY, USA

$19 *$ Co-corresponding author

20 Contact: catarina.hioe@ mssm.edu, catarina.hioe@va.gov

21 Summary of main points (40 words): $\operatorname{IgM}, \operatorname{IgG} 1$ and $\operatorname{IgA} 1$ antibodies against SARS-CoV-2 spike 22 glycoprotein and its receptor-binding domain are present in convalescent COVID-19 plasma. Like IgG, $23 \operatorname{IgM}$ and $\operatorname{Ig} \mathrm{A}$ contribute to virus neutralization, providing the basis for optimal selection of convalescent 24 plasma for COVID-19 treatment. 
medRxiv preprint doi: https://doi.org/10.1101/2020.08.18.20177303; this version posted December 21, 2020. The copyright holder for this preprint (which was not certified by peer review) is the author/funder, who has granted medRxiv a license to display the preprint in perpetuity.

It is made available under a CC-BY-NC-ND 4.0 International license .

\section{Footnotes:}

$27{ }^{a}$ This study was supported by the Microbiology Laboratory Clinical Services at the Mount Sinai Health 28 System and the Mount Sinai Health System Translational Science Hub; the Department of Medicine of the 29 Icahn School of Medicine at Mount Sinai Department of Medicine (to S.Z-P., C.E.H.); the Department of 30 Microbiology and the Ward-Coleman estate for endowing the Ward-Coleman Chairs at the Icahn School 31 of Medicine at Mount Sinai (to B.L.), the Department of Veterans Affairs [Merit Review Grant 32 I01BX003860] (to C.E.H.) and [Research Career Scientist Award 1IK6BX004607] (to C.E.H.); the

33 National Institutes of Health [grant AI139290] to C.E.H., [grants R01 AI123449, R21 AI1498033] to B.L, 34 and [grant U54TR001433]. K.Y.O. and C.S. were supported by Viral-Host Pathogenesis Training Grant 35 T32 AI07647; K.Y.O. was additionally supported by F31 AI154739. S.I. and C-T. H. were supported by 36 postdoctoral fellowships from CHOT-SG (Fukuoka University, Japan) and the Ministry of Science and 37 Technology (MOST, Taiwan), respectively.

$39{ }^{\mathrm{b}}$ The authors declare no competing interests.

40

$41 *$ Co-corresponding author

42 Contact: $\underline{\text { catarina.hioe@ } @ s s m . e d u}, \underline{\text { catarina.hioe@ } \mathrm{va.gov}}$ 
medRxiv preprint doi: https://doi.org/10.1101/2020.08.18.20177303; this version posted December 21, 2020. The copyright holder for this preprint (which was not certified by peer review) is the author/funder, who has granted medRxiv a license to display the preprint in perpetuity. It is made available under a CC-BY-NC-ND 4.0 International license.

\section{Abstract - 160 words}

45 Background: SARS-CoV-2 has infected millions of people globally. Virus infection requires the 46 receptor-binding domain (RBD) of the spike protein. Although studies have demonstrated anti-spike and $47 \quad \mathrm{RBD}$ antibodies to be protective in animal models, and convalescent plasma as a promising therapeutic 48 option, little is known about immunoglobulin (Ig) isotypes capable of blocking infection.

49 Methods: We studied spike- and RBD-specific Ig isotypes in convalescent and acute plasma/sera using a 50 multiplex bead assay. We also determined virus neutralization activities in plasma, sera, and purified Ig 51 fractions using a VSV pseudovirus assay.

52 Results: Spike- and RBD-specific IgM, IgG1, and IgA1 were produced by all or nearly all subjects at 53 variable levels and detected early after infection. All samples displayed neutralizing activity. Regression 54 analyses revealed that $\operatorname{IgM}$ and $\operatorname{IgG} 1$ contributed most to neutralization, consistent with $\operatorname{IgM}$ and $\operatorname{IgG}$ 55 fractions' neutralization potency. IgA also exhibited neutralizing activity, but with lower potency. 56 Conclusion: $\operatorname{IgG}$, IgM and IgA are critical components of convalescent plasma used for COVID-19 57 treatment.

\section{Keywords}

60 SARS-CoV-2, COVID-19, antibody isotypes, neutralization, convalescent plasma 


\section{Text -3499 words}

\section{Background}

63

Since the first patients with coronavirus disease 2019 (COVID-19), caused by severe acute respiratory syndrome coronavirus 2 (SARS-CoV-2), were identified in Wuhan, China [1], the epidemic has spread worldwide, infecting millions of people. Effective therapeutics and vaccines are urgently needed. Convalescent plasma transfusions have shown promising results in patients with severe COVID19 [2-4] and clinical trials to evaluate its efficacy for ambulatory and hospitalized patients are underway [5-7]. To this end, information is needed about immunoglobulin (Ig) isotypes in convalescent plasma that have antiviral activities. The data would likewise inform vaccine development [8]. Most vaccines are based on the SARS-CoV-2 spike protein [8,9], which is a membrane-anchored protein present on the virus envelope along with two others (membrane and envelope proteins) and contains the receptor-binding domain (RBD) for binding and entry into cells [10-12]. The vaccines aim to protect by inducing neutralizing antibodies (Abs) that block viral infection.

SARS-CoV-2 spike-, RBD- and nucleocapsid-specific serum and plasma Abs of IgM, IgG, and IgA isotypes are found in most COVID-19 patients [13-18], with neutralizing activities developing within two weeks of infection and declining over time $[15,16,19,20]$. However, the neutralizing titers vary greatly $[15,16,19,20]$ and correlate with Ab binding levels against RBD, spike, and/or nucleocapsid, and with age, symptom duration, and symptom severity $[15,16]$. Several RBD-specific monoclonal IgG Abs with neutralizing activity have been generated, and these confer protection in animal models $[15,19,21,22]$. A monoclonal $\mathrm{Ab}$ of IgA isotype recognizing both SARS-CoV-1 and SARS-CoV-2 spike proteins and blocking ACE2 receptor binding was recently described [23]. However, no direct evidence is available regarding the neutralizing capacity of plasma IgM and IgA from COVID-19 patients. 
84 mediate virus neutralization, and their relative contribution depends on the physiologic compartment in

85 which they are found, with IgA contributing to the protection of mostly the upper respiratory tract while

86 IgG was protecting the lower respiratory tract [24,25]. An anti-hemagglutinin monoclonal polymeric IgA

87 has been demonstrated to mediate more potent anti-influenza activities than monoclonal IgG against the

88 same epitope [26]. An IgM monoclonal Ab with neutralizing activity against influenza B has also been

89 described [27]. In addition, respiratory syncytial virus (RSV)-specific mucosal IgA are a better correlate

90 of protection than serum IgG counterparts [28]. In the case of SARS-CoV-1, high titers of IgA in the lungs

91 correlated with reduced pathology in animal models [29]. Whether $\operatorname{IgA}$ in the blood and the respiratory

92 tract mucosa offer protection against SARS-CoV-2 remains an open question. Moreover, scant data are

93 available regarding IgM contribution to neutralization and protection against viruses, including SARS-

94 CoV-2. Of note, in terminally ill patients, systemic SARS-CoV-2 infection affects multiple organs [30].

95 Thus, the capacity of plasma Ig to suppress virus spread is critical for effective therapy against severe

96 COVID-19.

We recently described a multiplex bead Ab-binding assay using the Luminex technology to detect

98 total Ig against spike and RBD [31]. Here we characterized the Ig isotype profiles using the Luminex

99 assay that detects spike- and RBD-specific IgM, IgG1-4, and IgA1-2. Using a pseudovirus assay [32], we

100 also measured plasma or serum neutralization and determined the neutralizing capacity of $\operatorname{IgM}, \operatorname{Ig} \mathrm{A}$, and

101 IgG fractions. The data indicate a high prevalence of spike- and RBD-specific IgM and $\operatorname{IgA}$, similar to that

102 of IgG1, in plasma and sera from COVID-19 patients, and their contributions to virus neutralization. In

103 addition, by testing purified $\operatorname{IgG}, \operatorname{IgM}$ and $\operatorname{Ig} \mathrm{A}$ fractions from convalescent plasma, this study presents the

104 first direct evidence that plasma $\operatorname{IgG}, \operatorname{IgM}$, and IgA all contribute to SARS-CoV-2 neutralization.

\section{Methods}

Recombinant proteins. SARS-CoV-2 spike and RBD proteins were produced as described

$107 \quad[33,34]$. 
Human samples. All COVID-19-positive and -negative samples tested in this study are tabulated

in Supplementary Table 1. Twenty-five citrated COVID-19 convalescent plasma samples destined for

110 transfusion to SARS-CoV-2-infected individuals (TF\#1-25, collected between March $26^{\text {th }}$ and April $7^{\text {th }}$

$1112020)$ and ten contemporary COVID-19-negative specimens (N\#4-13) were obtained from the Division of

112 Transfusion Medicine of the Department of Pathology, Molecular and Cell-Based Medicine (Mount Sinai

113 Hospital System, IRB \#20-03574). The convalescent specimens TF\#1-25 were from donors pre-screened

114 to have serum IgG reciprocal titer $\geq 320$ in the Mount Sinai Hospital ELISA anti-IgG COVID-19 assay.

115 Four sera from de-identified COVID-19 individuals (P\#5-8) were provided by the Clinical Pathology

116 Division of the Department of Pathology, Molecular and Cell-Based Medicine at the Icahn School of

117 Medicine at Mount Sinai. The following samples were obtained from volunteers enrolled in IRB-approved

118 protocols at the Icahn School of Medicine at Mount Sinai (IRB \#16-00772, \#16-00791, \#17-01243) and

119 the James J. Peter Veterans Affairs Medical Center (IRB \#BAN-1604): sera from seven participants with

120 documented SARS-CoV-2 infection (P\#1 d8, d11, and d15 after symptom onset, P\#2 d7 and d10 after

121 symptom onset, and RP\#1-5 after convalescence), and pre-pandemic sera from twelve healthy donors

122 (N\#1-3, N\#14-22). All study participants provided written consent. All samples were heat-inactivated

123 before use.

Ig fractionation. IgA was isolated first from plasma using peptide M agarose beads (InvivoGen

\#GEL-PDM). The pass-through plasma was enriched sequentially for IgG using protein G agarose beads

126 (InvivoGen \#GEL-AGG) and for IgM using a HiTrap IgM column (G.E. Healthcare \#17-5110-01). An

127 additional step was performed using Protein A Plus mini-spin columns to separate IgG from IgM. Protein

128 concentrations were determined with Nanodrop (Thermo Scientific).

Multiplex bead Ab binding assay. SARS-CoV-2 spike and RBD antigens were coupled to beads

130 and experiments performed as described [31] except for the use of different secondary Abs designated in

131 the figure legends. 
medRxiv preprint doi: https://doi.org/10.1101/2020.08.18.20177303; this version posted December 21, 2020. The copyright holder for this preprint (which was not certified by peer review) is the author/funder, who has granted medRxiv a license to display the preprint in perpetuity.

It is made available under a CC-BY-NC-ND 4.0 International license .

132

133

134

135

136

137

138

139

140

141

142

143

144

145 Results

146

147

148

149

150

151

152

153

154

155

COV2pp production and titration. SARS-CoV-2 pseudoviruses (COV2pp) with wild-type (WT)

or D614G-mutated spike proteins were produced as described [32]. Pseudoviruses were titrated on 20,000

Vero-CCL81 cells seeded 24 hours before infection. At 18-22 hours post-infection, the infected cells were washed and Renilla luciferase activity was measured with the Renilla-Glo ${ }^{\mathrm{TM}}$ Luciferase Assay System (Promega \#E2720) on a Cytation3 (BioTek) instrument.

COV2pp neutralization. Virus was pre-incubated with diluted samples for 30 minutes. The virussample mix was then added to Vero-CCL81 cells seeded 24 hours earlier and spinoculated. Infection was measured after 18-22 hours by luciferase activity.

The percentage of neutralization was calculated as follows: 100-([sample RLU - cell control $\mathrm{RLU}] /$ virus control RLU)*100. $\mathrm{IC}_{50}$ and $\mathrm{IC}_{90}$ titers were calculated as the reciprocal sample dilution or purified Ig fraction concentration achieving 50\% and 90\% neutralization, respectively.

Statistical analysis. Two-tailed Mann-Whitney test, Spearman rank-order correlation test, and simple linear regressions were performed as designated in the figure legends using GraphPad Prism 8.

\section{Levels of Ig isotypes against the SARS-CoV-2 spike and RBD vary in convalescent}

individuals. A total of 29 serum (P\#5-8) and plasma (TF\#1-25) specimens from COVID-19 convalescent individuals was tested. TF\#1-25 were collected 4-8 weeks after the initial outbreak in North American, and used for transfusion into hospitalized COVID-19 patients [2]. Ten plasma from COVID-negative contemporaneous blood bank donors (N\#4-13) were included for comparison. Sera or plasma from 12 uninfected individuals banked prior to the COVID-19 outbreak (N\#1-3 and N\#14-22) were used to establish background values. The specimens were initially titrated for total Ig against spike and RBD (Fig. 1). All 29 COVID-19 positive specimens exhibited titration curves of total Ig Abs against spike, while none of the negative controls displayed reactivity. Similar results were observed with RBD, except that one contemporaneous COVID-19-negative sample had a low level of RBD-specific Ig (N\#10). Overall, 
156 the background MFI values were higher for RBD than spike. To assess the reproducibility of the assay, the samples were tested in at least two separate experiments run on different days, and a strong correlation was observed between the MFI values from these independent experiments (Supplementary Fig. 1). The areas under the curves (AUCs) highly correlated with the MFI values from specimens diluted 1:200 (p <0.0001; Supplementary Fig. 2); consequently, all samples were tested for isotyping at this dilution. At the 1:200 dilution we were able to discern a diverse range of Ig isotype levels among individual samples

(Fig. 2). To evaluate for the presence of spike-specific and RBD-specific total Ig, IgM, IgG1, IgG2, IgG3,

$163 \mathrm{IgG} 4, \operatorname{Ig} \mathrm{A} 1$ and IgA2, the specificity and strength of the secondary Abs used to detect the different

isotypes were first validated with Luminex beads coated with myeloma proteins of known Ig isotypes

specific Ig isotypes with MFI values reaching >60,000 (Supplementary Fig. 3).

All 29 convalescent individuals had anti-spike and anti-RBD total Ig (Fig. 2), but the Ig levels

were highly variable, with MFI values ranging from 36,083 to 190,150. In addition, all 29 convalescent

individuals also displayed IgM Abs against spike at varying levels, and 93\% were positive for anti-RBD

$170 \operatorname{IgM}$ when evaluated using cut-off values calculated as mean +3 standard deviation (SD) of the 12 pre-

171 pandemic samples (Fig 2b, c). An IgG1 response was detected against both spike and RBD in 97\% of the

172 convalescent subjects, with MFI values that ranged from 1,013 to 59,880. In contrast, $\operatorname{IgG} 2, \operatorname{IgG} 3$, and

173 IgG4 Abs against spike and RBD were detected in only a small fraction of the subjects, and the levels

174 were very low (MFI <1,300) (Fig. 2). Surprisingly, almost all individuals produced IgA1 Abs against

175 spike (97\%) and RBD (93\%), while 17\% exhibited IgA2 against spike, and 48\% exhibited IgA2 against

176 RBD (Fig. 2). Low levels, slightly above cut-off, of spike- and RBD-binding total Ig, IgM, IgG1, and

177 IgA1 were detected sporadically in contemporaneous COVID-19 samples, such as N\#8, N\#10, and N\#11.

178 The responses against spike and RBD were highly correlated for every isotype (Supplementary Fig. 4).

179 Overall, these data demonstrate that IgM, IgG1, and IgA1 Abs were induced against spike and RBD in all 
180 or almost all COVID-19 convalescent individuals (Fig. 2). The levels, however, were highly variable

181 among individuals. No significant difference was observed between female and male individuals

182 (Supplementary Fig. 5).

183 In Fig. 3, regression analyses to assess the impact of individual isotypes on the total Ig binding

184 showed that IgG1 had the highest $\mathrm{r}^{2}$ values ( 0.83 and 0.70 for spike- and RBD-binding $\operatorname{IgG} 1$, respectively)

185 with $\mathrm{p}<0.0001$, indicating that $\mathrm{IgG1}$ is the major isotype induced by SARS-CoV-2 infection against spike

186 and RBD (Fig. 3a,b). IgG2 Abs against RBD had an $r^{2}$ value of 0.55 with $\mathrm{p}<0.0001$, but IgG2 levels were

187 very low. For all other isotypes, including IgM, the $r^{2}$ values were $<0.40$ (Fig. 3c). Thus, despite the

188 presence of many isotypes in sera and plasma, as expected, the major isotype of spike and RBD-specific

189 Abs is IgG1.

190 Specimens from two patients (P\#1 and P\#2) were drawn during the acute phase of the infection.

191 Serial specimens from these patients were tested to determine the isotypes of Abs present early in

192 infection. The earliest samples from both patients, drawn at 7 or 8 days after symptom onset were already

193 positive for total Ig, IgG1, IgA1 and IgM Abs against spike and RBD (Supplementary Fig. 6), and these

194 levels increased over the following three to seven days. On the contrary, IgA2 Ab levels were near or

195 below background on days 7-8 and remained unchanged over the two weeks post-onset. IgG4 Abs also

196 remained low or near background, whereas IgG2 and IgG3 Abs increased slightly to above background

197 after 10-15 days.

Neutralizing activity is detected in specimens from all convalescent COVID-19 individuals.

199 We subsequently tested the ability of samples from convalescent subjects to neutralize a VSV $\Delta \mathrm{G}$

200 pseudovirus bearing the SARS-CoV-2 spike protein (COV2pp). This pseudovirus assay demonstrated a

201 strong positive correlation with neutralization of the authentic SARS-CoV-2 virus [32]. The titration of

202 neutralizing activity against the WT COV2pp is shown in Fig. 4a for specimens from 28 COVID-19

203 convalescent individuals and 11 uninfected individuals, tested over a range of seven serial four-fold 
204 dilutions. A soluble recombinant RBD (sRBD) protein capable of blocking virus infection was tested in parallel as a positive control.

All specimens from COVID-19 convalescent individuals were able to neutralize the virus at levels

above 50\% (Fig. 4a). For 26 of 28 specimens, neutralization reached $>90 \%$ (Fig. 4a). The sample with the

lowest titer (reciprocal $\mathrm{IC}_{50}$ titer $=37$ ) reached a neutralization plateau of only $\sim 60 \%$. Of note, one sample

(TF\#11) demonstrated highly potent neutralization with a reciprocal $\mathrm{IC}_{50}$ titer $>40,960$, and neutralization

was still $75 \%$ at the highest dilution tested. None of the samples from uninfected individuals reached $50 \%$

neutralization (Fig. 4a), while the sRBD positive control demonstrated potent neutralization with an $\mathrm{IC}_{50}$

of $0.06 \mu \mathrm{g} / \mathrm{mL}$ (Fig. 4a), similar to that recently reported [32].

The samples were also tested for neutralization against a COV2pp bearing the spike with a D614

mutation (D614G mutant), as the D614G variant has become the most prevalent circulating strain in the

global pandemic [35]. Similar to the WT COV2pp, all COVID-19-convalescent samples had neutralizing

activity reaching $>50 \%$, while none of the negative samples did (Fig. 4b). The $\mathrm{IC}_{90}$ titers against WT and

D614 mutant differed on average by only 1.7-fold and correlated strongly with each other (p<0.0001, Fig.

4c).

IgM and IgG1 contribute most to SARS-CoV-2 neutralization. Given our observation that Ab

isotype levels and neutralization titers varied tremendously among convalescent COVID-19 individuals

(Figs. 2 and 5), we investigated the relative contribution of each Ab isotype to the neutralizing activities.

Regression analyses were performed on 27 COVID-19 convalescent samples (TF\#11 was excluded due to

its outlier neutralization titer). As expected, relatively high $r^{2}$ values $(0.32-0.62)$ and significant $p$ values

were observed with total Ig, IgM and IgG1; in each case, $r^{2}$ values were higher for spike than for RBD

(Fig. 6a). The highest $\mathrm{r}^{2}$ value was achieved in the analysis of $\mathrm{IC}_{90}$ neutralizing titers and $\operatorname{IgM}$ binding to 
medRxiv preprint doi: https://doi.org/10.1101/2020.08.18.20177303; this version posted December 21, 2020. The copyright holder for this preprint (which was not certified by peer review) is the author/funder, who has granted medRxiv a license to display the preprint in perpetuity.

It is made available under a CC-BY-NC-ND 4.0 International license .

the capacity of different isotypes to mediate neutralization, we evaluated the neutralization activities of

$230 \mathrm{IgM}, \mathrm{IgG}$, and IgA fractions purified from the plasma of five COVID-19 convalescent individuals (RP\#1-

231 5). The enrichment of $\operatorname{IgM}$, IgG1, and IgA1 Abs reactive with spike and RBD was validated using the

232 isotyping method used above (Supplementary Fig. 7 and data not shown). These $\operatorname{IgM}, \operatorname{IgG}, \operatorname{and} \operatorname{IgA}$

233 fractions were then evaluated for neutralizing activity along with the original plasma (Fig. 7). The RP\#1-5

234 plasma neutralizing reciprocal $\mathrm{IC}_{50}$ titers ranged from 35 to 690 (Fig. 7a,b). Purified $\operatorname{IgM}$ and $\operatorname{IgG}$

235 fractions from RP\#1-5 all mediated neutralization reaching more than 50\%. Unexpectedly, plasma IgA

236 fractions also displayed neutralizing activity, although not with the same potency as $\operatorname{IgM}$ and $\operatorname{IgG}$ (Fig

237 7c,d). In contrast, IgM, IgG, and IgA fractions from the negative control (RN\#1) showed no neutralization

238 (Fig. 7c,d).

239 Discussion

240 Our study demonstrates that IgG1, IgA1 and IgM Abs against SARS-CoV-2 spike and RBD were

241 prevalent in plasma of convalescent COVID-19 patients approximately one to two months after infection.

242 These isotypes were present within 7-8 days after the onset of symptoms. Importantly, all three isotypes

243 showed the capacity to mediate virus neutralization. While regression analyses demonstrated the strongest

244 contributions of IgM and IgG1 to neutralizing activity, direct testing of purified isotype fractions showed

245 that IgA also were able to neutralize, indicating the protective potential of all three major Ig isotypes.

246 These data carry important implications for the use of convalescent plasma and hyperimmunoglobulin as

247 COVID-19 therapeutics, suggesting that their selection would optimally be based on the presence of all of

248 these Ig isotypes.

While all COVID-19 convalescent individuals exhibited neutralization activities reaching $>50 \%$

and 26 of 28 specimens attained $90 \%$ neutralization, neutralization levels were highly variable with $\mathrm{IC}_{50}$ 
252 Wuhan strain and the currently prevalent D614G strain of SARS-CoV-2. Similarly, the levels of spikeand RBD-binding total Ig and Ig isotypes varied greatly.

A trend toward higher levels of total Ig and each Ig isotype was seen in female compared to male subjects, as reported in another study [36]. Moreover, except for TF\#11 (a male elite neutralizer), the

median neutralizing $\mathrm{IC}_{90}$ titer was higher in females than males, although the difference did not reach significance (data not shown). Sex differences in Ab induction have been observed following influenza

vaccination in humans and mice and were shown to result from the impact of sex-related steroids [37].

Whether and to what extent this contributes to the sex differences seen in clinical outcomes of COVID-19

remains to be investigated. Other studies have shown that Ab levels were associated with multiple factors,

including time from disease onset [38] and disease severity [14]. However, other than sex, clinical data are not available for the subjects studied here, limiting our analysis only to neutralization and Ig isotypes.

One remarkable finding from our study is that although neutralization titers correlated with binding

264 levels of $\operatorname{IgM}$ and IgG1 and not with those of $\operatorname{Ig} \mathrm{A} 1$ or $\operatorname{IgA}$, purified IgA fractions from convalescent

265 COVID-19 patients exhibited significant neutralizing activities. The importance of this finding is

underscored by the data showing that IgA1 was the prominent isotype in some samples such as TF\#7 and

TF\#24 and that IgA1 could be detected early after symptom onset. Data from other studies also support

the significance of $\operatorname{IgA}$ in that purified $\operatorname{Ig} \mathrm{A}$ fractions exhibited more, or as potent neutralizing activities as

purified $\mathrm{IgG}$, and that RBD-binding $\operatorname{IgA}$ correlated as strongly as $\operatorname{IgG}$ with micro-neutralization titers

[39]. IgA were also detected in saliva and bronchoalveolar lavage from COVID-19 patients [40].

271 Nonetheless, Wang et al. reported that plasma IgA monomers were less potent than the plasma IgG and secretory IgA counterparts [41]. In our study, neutralization activities detected in the IgA fractions were mediated mainly by IgA1, the predominant IgA isotype in plasma, and the $\mathrm{IC}_{50}$ potency of the $\operatorname{Ig} \mathrm{A}$

274 fraction was $\sim 4$-fold lower than the potency of $\operatorname{IgM}$ and IgG1 fractions. This difference cannot be 
276 spike-specific monoclonal IgA and IgM Abs yielded similar IgA and IgM concentrations in the respective purified fractions (median of 2 and $2.5 \mu \mathrm{g} / \mathrm{mL}$ respectively). Fine epitope specificities and affinities may differ for $\operatorname{IgA}$, IgM, and IgG to impact neutralization potency, but have yet to be evaluated.

In addition to neutralization, non-neutralizing $\mathrm{Ab}$ activities have been implicated in protection

280 from various virus infection through potent Fc-mediated functions such as antibody-dependent cellular

281 cytotoxicity (ADCC), antibody-dependent cellular phagocytosis (ADCP), and complement-mediated lysis;

282 this is reported for HIV, influenza, Marburg, and Ebola viruses [25,42-44]. The Fc activities were not 283 evaluated in our study, and their contribution to protection against SARS-CoV-2 is yet unclear [45,46]. A recent study demonstrated enrichment of spike-specific IgM and IgA1 Abs and spike-specific phagocytic and antibody-dependent complement deposition (ADCD) activity in plasma of individuals who recovered from SARS-CoV-2 infection, while nucleocapsid-specific IgM and IgA2 responses and nucleocapsidspecific ADCD activity were features enriched in deceased patients [47]. DNA vaccines expressing fulllength and truncated spike proteins could curtail SARS-CoV-2 infection in the respiratory tract by varying degrees in rhesus macaques. This virus reduction correlated with levels of neutralization and also with Fcmediated effector functions such as ADCD [45]. Interestingly, these DNA vaccines elicited spike- and RBD-specific IgG1, IgG2, IgG3, IgA, and IgM Abs, and similar to our findings, neutralization correlated variants also showed varying protection levels, and virus reduction correlated best with neutralizing titers potential of Abs against SARS-CoV-2_-including neutralizing, non-neutralizing, and enhancing activities — are vital for determining the optimal Ab treatment modalities against COVID-19 and the potential efficacy of COVID-19 vaccine candidates.

When we examined plasma specimens collected within 7-8 days after COVID-19 symptom onset, 299 we detected IgG and IgA against spike and RBD, as well as IgM. This is consistent with published reports 
medRxiv preprint doi: https://doi.org/10.1101/2020.08.18.20177303; this version posted December 21, 2020. The copyright holder for this preprint (which was not certified by peer review) is the author/funder, who has granted medRxiv a license to display the preprint in perpetuity.

It is made available under a CC-BY-NC-ND 4.0 International license .

300 showing that $100 \%$ of COVID-19-infected individuals developed IgG within 19 days after symptom onset

301 and that $\operatorname{IgG}$ and $\operatorname{IgM}$ seroconversion could occur simultaneously [14]. IgA were also found early after

302 infection (4-6 days after symptom onset) and increased over time $[13,18,40]$. These studies suggest that

303 measuring total $\mathrm{Ig}$, rather than $\mathrm{IgG}$, could contribute to improved outcomes for early disease diagnosis.

304 We found no correlation between the levels of different isotypes in the specimens examined in our study

305 (data not shown). Of note, IgA presence early during acute infection may suggest the potential

306 contribution of natural $\operatorname{IgA}$, which, similar to natural $\operatorname{IgM}$, arises spontaneously from innate B1 cells to

307 provide the initial humoral responses before the induction of adaptive classical B cells [49].

308 In summary, this study demonstrates that spike- and RBD-specific IgM, IgG1, and IgA1 are

309 produced by all or almost all analyzed COVID-19 convalescent subjects and can be detected at early

310 stages of infection. The plasma samples of convalescent individuals also display neutralization activities

311 mediated by $\operatorname{IgM}$, IgG, and IgA1, although neutralization titers correlated more strongly with IgM and

312 IgG levels. The contribution of IgM, IgG, and IgA to SARS-CoV-2-neutralizing activities demonstrates

313 their importance in the efficacy of passively transferred Abs for SARS-CoV-2 treatment.

315 References

316 1. Zhu N, Zhang D, Wang W, et al. A Novel Coronavirus from Patients with Pneumonia in China,

317 2019. N Engl J Med. 2020; 382(8):727-733.

318 2. Liu STH, Lin H-M, Baine I, et al. Convalescent plasma treatment of severe COVID-19: a

319 propensity score-matched control study. Nat Med. 2020; .

3203 . Zeng H, Wang D, Nie J, et al. The efficacy assessment of convalescent plasma therapy for

321 COVID-19 patients: a multi-center case series. Signal Transduct Target Ther. Nature Publishing Group;

$322 \quad 2020 ; 5(1): 1-12$.

323 4. Ibrahim D, Dulipsingh L, Zapatka L, et al. Factors Associated with Good Patient Outcomes 
324 Following Convalescent Plasma in COVID-19: A Prospective Phase II Clinical Trial. Infect Dis Ther.

2020; : $1-14$.

326 5. Janssen M, Schäkel U, Fokou CD, et al. A Randomized Open label Phase-II Clinical Trial with or

327 without Infusion of Plasma from Subjects after Convalescence of SARS-CoV-2 Infection in High-Risk

328 Patients with Confirmed Severe SARS-CoV-2 Disease (RECOVER): A structured summary of a study

329 protocol for a randomised controlled trial. Trials. BioMed Central; 2020; 21(1):1-4.

330 6. Convalescent Plasma to Limit SARS-CoV-2 Associated Complications - Full Text View -

331 ClinicalTrials.gov [Internet]. [cited 2020 Nov 2]. Available from:

332 https://clinicaltrials.gov/ct2/show/NCT04373460

333 7. Convalescent Plasma in Outpatients With COVID-19 - Full Text View - ClinicalTrials.gov

334 [Internet]. [cited 2020 Nov 2]. Available from: https://clinicaltrials.gov/ct2/show/NCT04355767

335 8. Le TT, Andreadakis Z, Kumar A, et al. The COVID-19 vaccine development landscape. Nat Rev

336 Drug Discov. Nature Publishing Group; 2020; 19(5):305-306.

337 9. Amanat F, Krammer F. SARS-CoV-2 Vaccines: Status Report. Immunity. 2020; .

338 10. Yan R, Zhang Y, Li Y, Xia L, Guo Y, Zhou Q. Structural basis for the recognition of SARS-CoV-

3392 by full-length human ACE2. Science. 2020; 367(6485):1444-1448.

340 11. Hoffmann M, Kleine-Weber H, Schroeder S, et al. SARS-CoV-2 Cell Entry Depends on ACE2

341 and TMPRSS2 and Is Blocked by a Clinically Proven Protease Inhibitor. Cell. 2020; 181(2):271-280.e8.

342 12. Walls AC, Park Y-J, Tortorici MA, Wall A, McGuire AT, Veesler D. Structure, Function, and

343 Antigenicity of the SARS-CoV-2 Spike Glycoprotein. Cell. 2020; 181(2):281-292.e6.

344 13. Ma H, Zeng W, He H, et al. Serum IgA, IgM, and IgG responses in COVID-19. Cell Mol

345 Immunol. Nature Publishing Group; 2020; 17(7):773-775.

346 14. Long Q-X, Liu B-Z, Deng H-J, et al. Antibody responses to SARS-CoV-2 in patients with

347 COVID-19. Nat Med. Nature Publishing Group; 2020; 26(6):845-848. 
medRxiv preprint doi: https://doi.org/10.1101/2020.08.18.20177303; this version posted December 21, 2020. The copyright holder for this preprint (which was not certified by peer review) is the author/funder, who has granted medRxiv a license to display the preprint in perpetuity.

It is made available under a CC-BY-NC-ND 4.0 International license .

348 15. Robbiani DF, Gaebler C, Muecksch F, et al. Convergent antibody responses to SARS-CoV-2 in 349 convalescent individuals. Nature. 2020; .

350 16. Okba NMA, Müller MA, Li W, et al. Severe Acute Respiratory Syndrome Coronavirus 2-Specific

351 Antibody Responses in Coronavirus Disease Patients. Emerg Infect Dis. 2020; 26(7):1478-1488.

352 17. Guo L, Ren L, Yang S, et al. Profiling Early Humoral Response to Diagnose Novel Coronavirus

353 Disease (COVID-19). Clin Infect Dis Off Publ Infect Dis Soc Am. 2020; .

354 18. Padoan A, Sciacovelli L, Basso D, et al. IgA-Ab response to spike glycoprotein of SARS-CoV-2 in 355 patients with COVID-19: A longitudinal study. Clin Chim Acta. 2020; 507:164-166.

356 19. Ju B, Zhang Q, Ge J, et al. Human neutralizing antibodies elicited by SARS-CoV-2 infection.

357 Nature. 2020; .

358 20. Prévost J, Gasser R, Beaudoin-Bussières G, et al. Cross-Sectional Evaluation of Humoral 359 Responses against SARS-CoV-2 Spike. Cell Rep Med. 2020; 1(7):100126.

360 21. Rogers TF, Zhao F, Huang D, et al. Isolation of potent SARS-CoV-2 neutralizing antibodies and 361 protection from disease in a small animal model. Science [Internet]. American Association for the 362 Advancement of Science; 2020 [cited 2020 Jul 16]; . Available from:

363 https://science.sciencemag.org/content/early/2020/06/15/science.abc7520

364 22. Zost SJ, Gilchuk P, Case JB, et al. Potently neutralizing and protective human antibodies against 365 SARS-CoV-2. Nature. Nature Publishing Group; 2020; :1-10.

366 23. Ejemel M, Li Q, Hou S, et al. IgA MAb blocks SARS-CoV-2 Spike-ACE2 interaction providing 367 mucosal immunity. BioRxiv Prepr Serv Biol. 2020; .

368 24. Renegar KB, Small PA, Boykins LG, Wright PF. Role of IgA versus IgG in the control of 369 influenza viral infection in the murine respiratory tract. J Immunol Baltim Md 1950. 2004; 173(3):19783701986.

371 25. Krammer F. The human antibody response to influenza A virus infection and vaccination. Nat Rev 
372 Immunol. 2019; 19(6):383-397.

373 26. Muramatsu M, Yoshida R, Yokoyama A, et al. Comparison of antiviral activity between IgA and

374 IgG specific to influenza virus hemagglutinin: increased potential of IgA for heterosubtypic immunity.

375 PloS One. 2014; 9(1):e85582.

376 27. Shen C, Zhang M, Chen Y, et al. An IgM antibody targeting the receptor binding site of influenza

377 B blocks viral infection with great breadth and potency. Theranostics. 2019; 9(1):210-231.

378 28. Habibi MS, Jozwik A, Makris S, et al. Impaired Antibody-mediated Protection and Defective IgA

379 B-Cell Memory in Experimental Infection of Adults with Respiratory Syncytial Virus. Am J Respir Crit

380 Care Med. 2015; 191(9):1040-1049.

381 29. Du L, He Y, Zhou Y, Liu S, Zheng B-J, Jiang S. The spike protein of SARS-CoV--a target for

382 vaccine and therapeutic development. Nat Rev Microbiol. 2009; 7(3):226-236.

383 30. Schurink B, Roos E, Radonic T, et al. Viral presence and immunopathology in patients with lethal

384 COVID-19: a prospective autopsy cohort study. Lancet Microbe. 2020; .

385 31. Weiss S, Klingler J, Hioe C, et al. A High Through-put Assay for Circulating Antibodies Directed

386 against the S Protein of Severe Acute Respiratory Syndrome Corona virus 2. medRxiv. Cold Spring

387 Harbor Laboratory Press; 2020; :2020.04.14.20059501.

388 32. Oguntuyo KY, Stevens CS, Hung C-T, et al. Quantifying absolute neutralization titers against

389 SARS-CoV-2 by a standardized virus neutralization assay allows for cross-cohort comparisons of

390 COVID-19 sera. medRxiv. Cold Spring Harbor Laboratory Press; 2020; :2020.08.13.20157222.

391 33. Amanat F, Stadlbauer D, Strohmeier S, et al. A serological assay to detect SARS-CoV-2

392 seroconversion in humans. Nat Med. Nature Publishing Group; 2020; :1-4.

393 34. Stadlbauer D, Amanat F, Chromikova V, et al. SARS-CoV-2 Seroconversion in Humans: A

394 Detailed Protocol for a Serological Assay, Antigen Production, and Test Setup. Curr Protoc Microbiol.

$3952020 ; 57(1):$ e100. 
396 35. Korber B, Fischer WM, Gnanakaran S, et al. Tracking Changes in SARS-CoV-2 Spike: Evidence 397 that D614G Increases Infectivity of the COVID-19 Virus. Cell. 2020; 182(4):812-827.e19.

398 36. Zeng F, Dai C, Cai P, et al. A comparison study of SARS-CoV-2 IgG antibody between male and 399 female COVID-19 patients: a possible reason underlying different outcome between gender. medRxiv. 400 Cold Spring Harbor Laboratory Press; 2020; :2020.03.26.20040709.

401 37. Potluri T, Fink AL, Sylvia KE, et al. Age-associated changes in the impact of sex steroids on 402 influenza vaccine responses in males and females. Npj Vaccines. Nature Publishing Group; 2019; 4(1):140312.

404 38. Long Q-X, Tang X-J, Shi Q-L, et al. Clinical and immunological assessment of asymptomatic 405 SARS-CoV-2 infections. Nat Med. Nature Publishing Group; 2020; :1-5.

406 39. Mazzini L, Martinuzzi D, Hyseni I, et al. Comparative analyses of SARS-CoV-2 binding (IgG, 407 IgM, IgA) and neutralizing antibodies from human serum samples. bioRxiv. Cold Spring Harbor $408 \quad$ Laboratory; 2020; :2020.08.10.243717.

409 40. Isho B, Abe KT, Zuo M, et al. Persistence of serum and saliva antibody responses to SARS-CoV-2 410 spike antigens in COVID-19 patients. Sci Immunol [Internet]. Science Immunology; 2020 [cited 2020 Oct 4119 9]; 5(52). Available from: https://immunology.sciencemag.org/content/5/52/eabe5511

412 41. Wang Z, Lorenzi JCC, Muecksch F, et al. Enhanced SARS-CoV-2 Neutralization by Secretory 413 IgA in vitro. bioRxiv. Cold Spring Harbor Laboratory; 2020; :2020.09.09.288555.

414 42. Horwitz, Bar-On Y, Lu C-L, et al. Non-neutralizing Antibodies Alter the Course of HIV-1 415 Infection In Vivo. Cell. 2017; .

416 43. Ilinykh PA, Huang K, Santos RI, et al. Non-neutralizing Antibodies from a Marburg Infection 417 Survivor Mediate Protection by Fc-Effector Functions and by Enhancing Efficacy of Other Antibodies. 418 Cell Host Microbe. 2020; 27(6):976-991.e11.

419 44. Gunn BM, Yu W-H, Karim MM, et al. A Role for Fc Function in Therapeutic Monoclonal 
medRxiv preprint doi: https://doi.org/10.1101/2020.08.18.20177303; this version posted December 21, 2020. The copyright holder for this preprint (which was not certified by peer review) is the author/funder, who has granted medRxiv a license to display the preprint in perpetuity. It is made available under a CC-BY-NC-ND 4.0 International license .

420 Antibody-Mediated Protection against Ebola Virus. Cell Host Microbe. 2018; 24(2):221-233.e5.

421 45. Yu J, Tostanoski LH, Peter L, et al. DNA vaccine protection against SARS-CoV-2 in rhesus 422 macaques. Science. 2020; .

423 46. Zohar T, Alter G. Dissecting antibody-mediated protection against SARS-CoV-2. Nat Rev

424 Immunol. 2020; 20(7):392-394.

425 47. Atyeo C, Fischinger S, Zohar T, et al. Distinct Early Serological Signatures Track with SARS-

426 CoV-2 Survival. Immunity [Internet]. 2020 [cited 2020 Aug 12]; . Available from:

427 http://www.sciencedirect.com/science/article/pii/S1074761320303277

428 48. Mercado NB, Zahn R, Wegmann F, et al. Single-shot Ad26 vaccine protects against SARS-CoV-2

429 in rhesus macaques. Nature. 2020; .

430 49. Meyer-Bahlburg A. B-1 cells as a source of IgA. Ann N Y Acad Sci. 2015; 1362:122-131.

431

432 
medRxiv preprint doi: https://doi.org/10.1101/2020.08.18.20177303; this version posted December 21, 2020. The copyright holder for this preprint (which was not certified by peer review) is the author/funder, who has granted medRxiv a license to display the preprint in perpetuity. It is made available under a CC-BY-NC-ND 4.0 International license.

\section{Acknowledgments}

434 We thank Dr. Florian Krammer, Dr. Viviana Simon, and Dr. Rebecca Powell for donation of samples and 435 reagents, and all the donors for their contribution to the research.

436

437 Author contributions

438 J.K., S.W., G.E-A., S.Z-P., and C.E.H. wrote and edited the manuscript. S.W., J.K., C.E.H., and S.Z-P.

439 designed the experiments. J.K., S.W., V.I., X.L. performed the experiments and collected the data. J.K.,

440 A.N., S.Z-P. and C.E.H. analyzed the data. K.Y.O., C.S., S.I., C-T.H., F.A., and B.L. provided protocols,

441 antigens, cells and pseudovirus stocks. G.E-A., I.B., S.A., J.C.B., E.M.K., J.S., S.L., D.J., and M.B-G.

442 provided specimens. All authors read and approved the final manuscript. 
medRxiv preprint doi: https://doi.org/10.1101/2020.08.18.20177303; this version posted December 21, 2020. The copyright holder for this preprint (which was not certified by peer review) is the author/funder, who has granted medRxiv a license to display the preprint in perpetuity. It is made available under a CC-BY-NC-ND 4.0 International license .

\section{Figure Legends}

444 Fig. 1. Titration of SARS-CoV-2 spike and RBD total Ig in plasma or serum samples from COVID-

44519 convalescent individuals. Titration of (a) spike-specific or (b) RBD-specific total Ig from 29 COVID44619 convalescent individuals, two acute COVID-19 patients with longitudinal samples, and 13 COVID-19 447 uninfected negative individuals. Specimens were diluted at 2-fold dilutions from 1:50 to 1:6,400.

Fig. 2. Levels of Ig isotypes against the SARS-CoV-2 spike and RBD vary in plasma or serum samples from COVID-19 convalescent individuals. Total Ig, IgM, IgG1, IgG2, IgG3, IgG4, IgA1 and IgA2 against (a) spike and (b) RBD in specimens from 29 COVID-19 convalescent individuals, 13 COVID-19 uninfected contemporaneous samples, and pre-pandemic controls were detected using the following secondary Abs: rabbit biotinylated-anti-human total Ig (Abcam, catalog \#ab97158) at $2 \mu \mathrm{g} / \mathrm{mL}$, mouse biotinylated-anti-human IgG1 Fc (Invitrogen \#MH1515) at $4 \mu \mathrm{g} / \mathrm{mL}$, mouse biotinylated-antihuman IgG2 Fc (Southern Biotech \#9060-08) at $1 \mu \mathrm{g} / \mathrm{mL}$, mouse biotinylated-anti-human IgG3 Hinge (Southern Biotech \#9210-08) at $3 \mu \mathrm{g} / \mathrm{mL}$, mouse biotinylated-anti-human IgG4 Fc (Southern Biotech \#9200-08) at $4 \mu \mathrm{g} / \mathrm{mL}$, mouse biotinylated-anti-human IgA1 Fc (Southern Biotech \#9130-08) at $4 \mu \mathrm{g} / \mathrm{mL}$, mouse biotinylated-anti-human IgA2 Fc (Southern Biotech \#9140-08) at $4 \mu \mathrm{g} / \mathrm{mL}$ or goat biotinylatedanti-human IgM (Southern Biotech \#2020-08) at $3 \mu \mathrm{g} / \mathrm{mL}$. The samples were tested at a dilution of 1:200 and data are shown as mean MFI + standard deviation (SD) of duplicate measurements from at least two independent experiments. The pre-pandemic controls are shown as mean MFI + SD of 12 samples (Pre, pre-pandemic samples for each of the isotypes. (c) Percentages of responders above the cut-off for each spike- or RBD-specific Ig isotype. 
medRxiv preprint doi: https://doi.org/10.1101/2020.08.18.20177303; this version posted December 21, 2020. The copyright holder for this preprint (which was not certified by peer review) is the author/funder, who has granted medRxiv a license to display the preprint in perpetuity.

It is made available under a CC-BY-NC-ND 4.0 International license .

467 regression of (a) spike-specific or (b) RBD-specific total Ig levels versus IgM, IgG1 or IgG2 levels versus

468 (c) spike-specific and RBD-specific IgG3, IgG4, IgA1, and IgA2 levels from the 29 COVID-19-

469 convalescent individuals from Fig. 1. The dash lines represent $95 \%$ confidence intervals.

Fig. 4. Neutralization activities are detected in all COVID-19 convalescent individuals. Neutralization

472 of COV2pp with (a) WT or (b) D614G mutated spike proteins by samples from 28 COVID-

473 19convalescent individuals and 11 COVID-19 uninfected individuals. The neutralizing activity of

474 recombinant soluble RBD (sRBD) is shown as a positive control. Twenty-four hours before infection,

47520,000 Vero-CCL81 cells/well were seeded. Virus $(82.5 \mu \mathrm{L} /$ well $)$ was pre-incubated with serially diluted

476 samples $(27.5 \mu \mathrm{L} /$ well, 4 -fold from 1:10 to 1:40,960) for 30 minutes at room temperature. The

477 virus/sample mix was then added to the cells and spinoculated by centrifugation (1250 rpm, 1 hour, room

478 temperature). Six virus-only and six medium-only wells were kept for each plate. After 18 to 22 hours at

$47937^{\circ} \mathrm{C}$, infection was measured by luciferase activity. sRBD was tested as a positive control at 4-fold

480 dilutions from 100 to $0.02 \mu \mathrm{g} / \mathrm{mL}$. The data are shown as mean percentage of neutralization + SD of

481 triplicates. The extrapolated titration curves were generated using a nonlinear regression model in

482 GraphPad Prism (Inhibitor versus response - variable slope [four parameters], least squares regression).

483 The dotted horizontal lines highlight $50 \%$ neutralization. (c) Spearman correlation between the IC 90 titers 484 against COV2pp WT vs. D614G.

485

486 Fig. 5. Summary of relative Ig isotype levels and neutralization titers. Table showing sex (purple, F:

487 female, M: male), relative levels of spike-specific (green) and RBD-specific (blue) Ig isotypes (+: bottom

488 quartile, ++ : second quartile, +++ : third quartile, ++++ : top quartile, -: non-responder) and reciprocal $\mathrm{IC}_{50}$

489 and $\mathrm{IC}_{90}$ neutralization titers against WT pseudovirus (orange) and D614G pseudovirus (red) of 29 plasma

490 samples from COVID-19 convalescent individuals. nd: not done. 
491 Fig. 6. IgM and IgG1 contribute most to SARS-CoV-2 neutralization. Simple linear regression of

492 reciprocal $\mathrm{IC}_{90}$ neutralization titers of 27 COVID-19 convalescent individuals versus (a) spike-specific or

493 (b) RBD-specific total Ig, IgM, IgG1 and IgA1 Ab levels. The black dash lines show the 95\% confidence

494 intervals. The dotted vertical red line represents the cut-off (mean of 12 pre-pandemic samples +3 SD) for

495 each isotype from Fig. 1. (c) Statistical results of simple linear regression analyses of reciprocal IC 90

496 neutralization titers of 27 COVID-19 convalescent individuals versus spike-specific or RBD-specific Abs

497 levels for IgG2-4 and IgA2.

498

499

Fig. 7. Purified IgM, IgG, and IgA fractions display neutralizing activities against SARS-CoV-2. (a)

500 Neutralization of COV2pp by five COVID-19-infected individual plasma samples (RP\#1-5) compared to

501 a specimen from a COVID-19 uninfected individual (RN\#1, green filled circles). Plasma samples were

502 tested at 4-fold dilutions from 1:10 to $1: 40,960$ or 1:20 to 1:81,920. Data are shown as the mean

503 percentage of neutralization. The dotted horizontal lines highlight $50 \%$ and $90 \%$ neutralization. (b)

504 Reciprocal $\mathrm{IC}_{50}$ and $\mathrm{IC}_{90}$ neutralization titers of RP\#1-5 plasma samples (c) Neutralization of COV2pp by

505 purified IgM, IgG, and IgA fractions from five COVID-19-infected individuals (RP\#1-5) compared to a

506 control Ig fraction (gray open triangles). IgA was isolated first from plasma samples by mixing 1:2 diluted

507 plasma with peptide $\mathrm{M}$ agarose beads $(600 \mu \mathrm{L} / 28 \mathrm{~mL}$ plasma, InvivoGen \#GEL-PDM) for 1.5 hours at

508 room temperature. After washing beads, IgA was eluted with a pH 2.8 buffer (Thermo Scientific \#21004)

509 and neutralized with pH 9 Tris buffer. The pass-through plasma sample was collected for IgG enrichment

510 using protein $\mathrm{G}$ agarose beads (InvivoGen \#GEL-AGG) and subsequently for IgM isolation using a

511 HiTrap IgM column (G.E. Healthcare \#17-5110-01). An additional purification step was performed using

512 Protein A Plus mini-spin columns to separate IgG from IgM. The fractions were tested at 4-fold dilutions

513 from 500 to $0.02 \mu \mathrm{g} / \mathrm{mL}$. Data are shown as the mean percentage of neutralization. The dotted horizontal

514 lines highlight $50 \%$ neutralization. (d) $\mathrm{IC}_{50}$ of purified $\mathrm{IgM}, \mathrm{IgG}$, and $\mathrm{IgA}$ fractions from RP\#1-5. The 
515 statistical significance was determined by a two-tailed Mann-Whitney test $(*: \mathrm{p}<0.05$, **: $\mathrm{p}<0.01)$.

517 Supplementary Fig. 1. Spearman correlations of (a) spike-specific or (b) RBD-specific total Ig MFI 518 values from two independent experiments to show the degree of assay reproducibility.

520 Supplementary Fig. 2. Spearman correlations of the area under the curves (AUCs) of (a) spike- or (b) 521 RBD-specific total Ig versus total Ig MFI values at a 1:200 dilution.

Supplementary Fig. 3. Isotyping validation was performed by coating Luminex beads with IgG1, IgG2,

$524 \operatorname{IgG} 3, \operatorname{IgG} 4, \operatorname{Ig} \mathrm{A} 1, \operatorname{Ig} \mathrm{A} 2$, and $\operatorname{IgM}$ myeloma proteins and detecting each with eight different secondary

525 Abs against total Ig, IgM, IgG1, IgG2, IgG3, IgG4, IgA1 and IgA2. The data are shown as mean MFI + 526 SD of duplicate.

527

528 Supplementary Fig. 4. Spearman correlations between spike-specific versus RBD-specific total Ig, IgM, $529 \operatorname{IgG1}$, IgG2, IgG3, IgG4, IgA1, or IgA2 MFI values.

530

531 Supplementary Fig. 5. Violin plots of (a) spike-specific or (b) RBD-specific total Ig, IgM, IgG1, and 532 IgA1 levels from nine COVID-19 convalescent female (F) and 15 male (M) subjects. The statistical 533 significance was determined by a two-tailed Mann-Whitney test (ns: non-significant: $\mathrm{p}>0.05$ ).

535 Supplementary Fig. 6. Induction of IgA1 and IgG1 along with IgM early after disease onset. Kinetics

536 of induction of spike-specific (left panel) or RBD-specific (right panel) total Ig, $\operatorname{IgM}, \operatorname{IgG} 1, \operatorname{IgG} 2, \operatorname{IgG} 3$, 537 IgG4, IgA1, and IgA2 from two COVID-19 patients. Longitudinal samples from each patient were tested 538 at a dilution of 1:200 in parallel with all negative samples and data are shown as mean MFI + SD of 
medRxiv preprint doi: https://doi.org/10.1101/2020.08.18.20177303; this version posted December 21, 2020. The copyright holder for this preprint (which was not certified by peer review) is the author/funder, who has granted medRxiv a license to display the preprint in perpetuity. It is made available under a CC-BY-NC-ND 4.0 International license .

539 duplicate measurements from at least two experiments. The dotted red line represents the cut-off value

540 calculated as the mean of 12 pre-pandemic samples +3 SD from Fig. 1.

541

542 Supplementary Fig. 7. Enrichment of spike-specific (a) IgM, (b) IgG, and (c) IgA in purified

543 fractions from RP\#1-5 and RN\#1. Each purified isotype fraction from plasma was measured for the

544 presence of $\operatorname{IgM}, \operatorname{IgG} 1, \operatorname{IgG} 2, \operatorname{IgG} 3, \mathrm{IgG} 4, \operatorname{IgA} 1$, and $\operatorname{Ig} \mathrm{A} 2$ Abs using the isotyping method validated in 545 Supplementary Fig. 3. 
Fig. 1. Titration of SARS-CoV-2 spike and RBD total Ig in plasma or serum samples from COVID-19 convalescent individuals. Titration of (a) spike-specific or (b) RBDspecific total Ig from 29 COVID-19 convalescent individuals, two acute COVID-19 patients with longitudinal samples, and 13 COVID-19 uninfected negative individuals. Specimens were diluted at 2-fold dilutions from 1:50 to 1:6,400. 
a
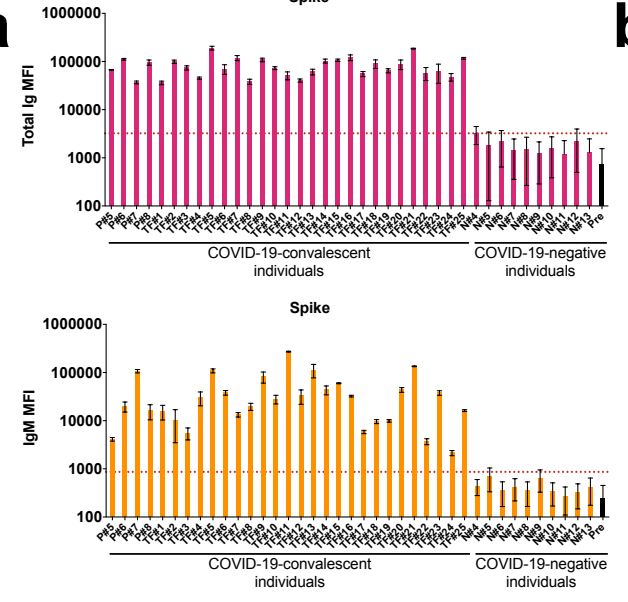

Spike
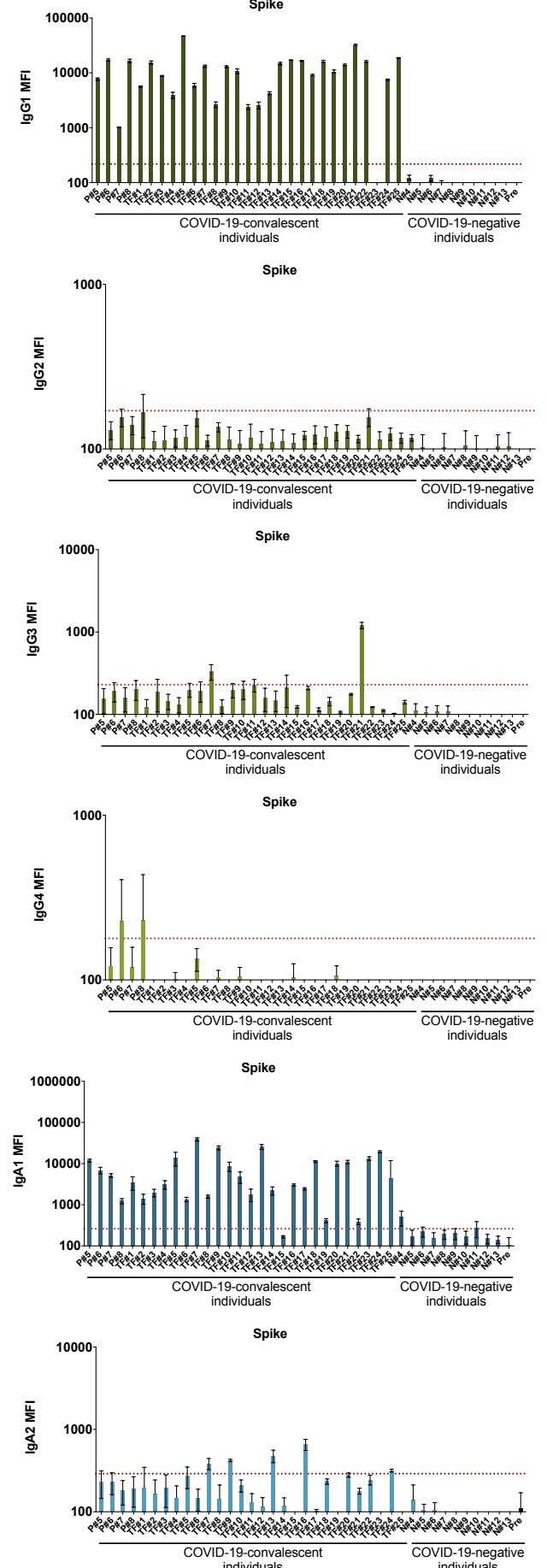

\begin{tabular}{|c|c|c|}
\hline & Spike & RBD \\
\hline Total Ig & $100 \%$ & $100 \%$ \\
\hline IgM & $100 \%$ & $93 \%$ \\
\hline IgG1 & $97 \%$ & $97 \%$ \\
\hline IgG2 & $\mathbf{0 \%}$ & $\mathbf{0} \%$ \\
\hline IgG3 & $\mathbf{7 \%}$ & $17 \%$ \\
\hline IgG4 & $7 \%$ & $3 \%$ \\
\hline IgA1 & $97 \%$ & $93 \%$ \\
\hline IgA2 & $17 \%$ & $48 \%$ \\
\hline
\end{tabular}
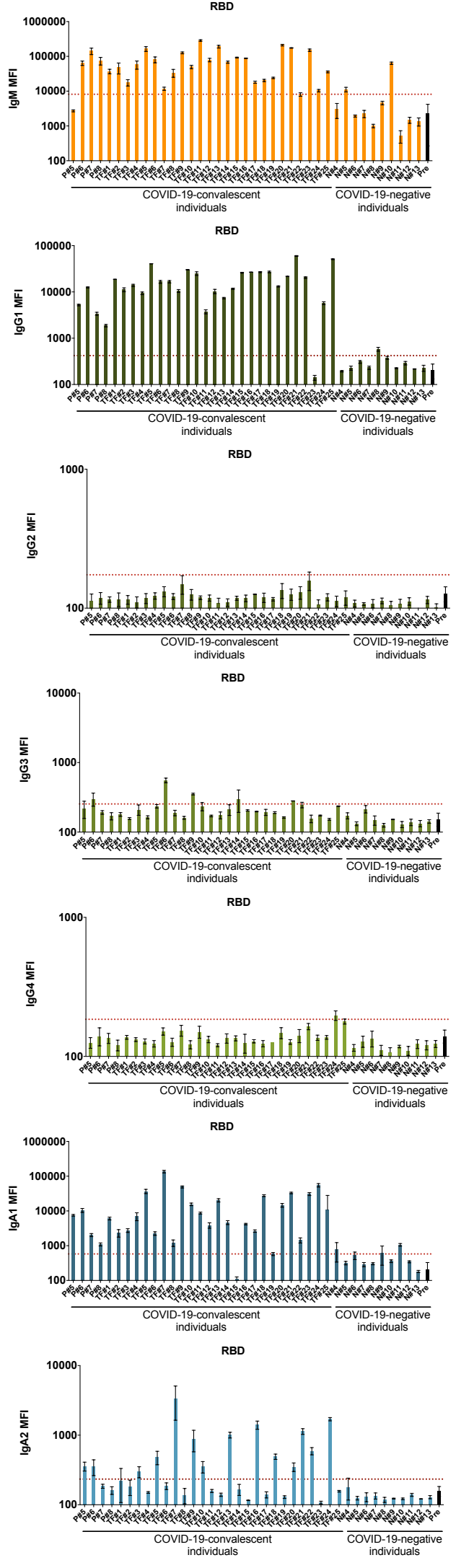
Fig. 2. Levels of Ig isotypes against the SARS-CoV-2 spike and RBD vary in plasma or

serum samples from COVID-19 convalescent individuals. Total $\operatorname{Ig}, \operatorname{IgM}, \operatorname{IgG} 1, \operatorname{IgG} 2$,

IgG3, IgG4, IgA1 and IgA2 against (a) spike and (b) RBD in specimens from 29 COVID-19

convalescent individuals, 13 COVID-19 uninfected contemporaneous samples, and pre-

pandemic controls were detected using the following secondary Abs: rabbit biotinylated-anti-

human total $\operatorname{Ig}$ (Abcam, catalog \#ab97158) at $2 \mu \mathrm{g} / \mathrm{mL}$, mouse biotinylated-anti-human IgG1

Fc (Invitrogen \#MH1515) at $4 \mu \mathrm{g} / \mathrm{mL}$, mouse biotinylated-anti-human IgG2 Fc (Southern

Biotech \#9060-08) at $1 \mu \mathrm{g} / \mathrm{mL}$, mouse biotinylated-anti-human IgG3 Hinge (Southern

Biotech \#9210-08) at $3 \mu \mathrm{g} / \mathrm{mL}$, mouse biotinylated-anti-human IgG4 Fc (Southern Biotech $\# 9200-08$ ) at $4 \mu \mathrm{g} / \mathrm{mL}$, mouse biotinylated-anti-human IgA1 Fc (Southern Biotech \#9130-08) at $4 \mu \mathrm{g} / \mathrm{mL}$, mouse biotinylated-anti-human IgA2 Fc (Southern Biotech \#9140-08) at 4 $\mu \mathrm{g} / \mathrm{mL}$ or goat biotinylated-anti-human IgM (Southern Biotech \#2020-08) at $3 \mu \mathrm{g} / \mathrm{mL}$. The samples were tested at a dilution of 1:200 and data are shown as mean MFI + standard deviation (SD) of duplicate measurements from at least two independent experiments. The pre-pandemic controls are shown as mean MFI + SD of 12 samples (Pre, black bar). The horizontal red dotted line represents the cut-off value determined as the mean $+3 \mathrm{SD}$ of 12 pre-pandemic samples for each of the isotypes. (c) Percentages of responders above the cutoff for each spike- or RBD-specific Ig isotype. 
a
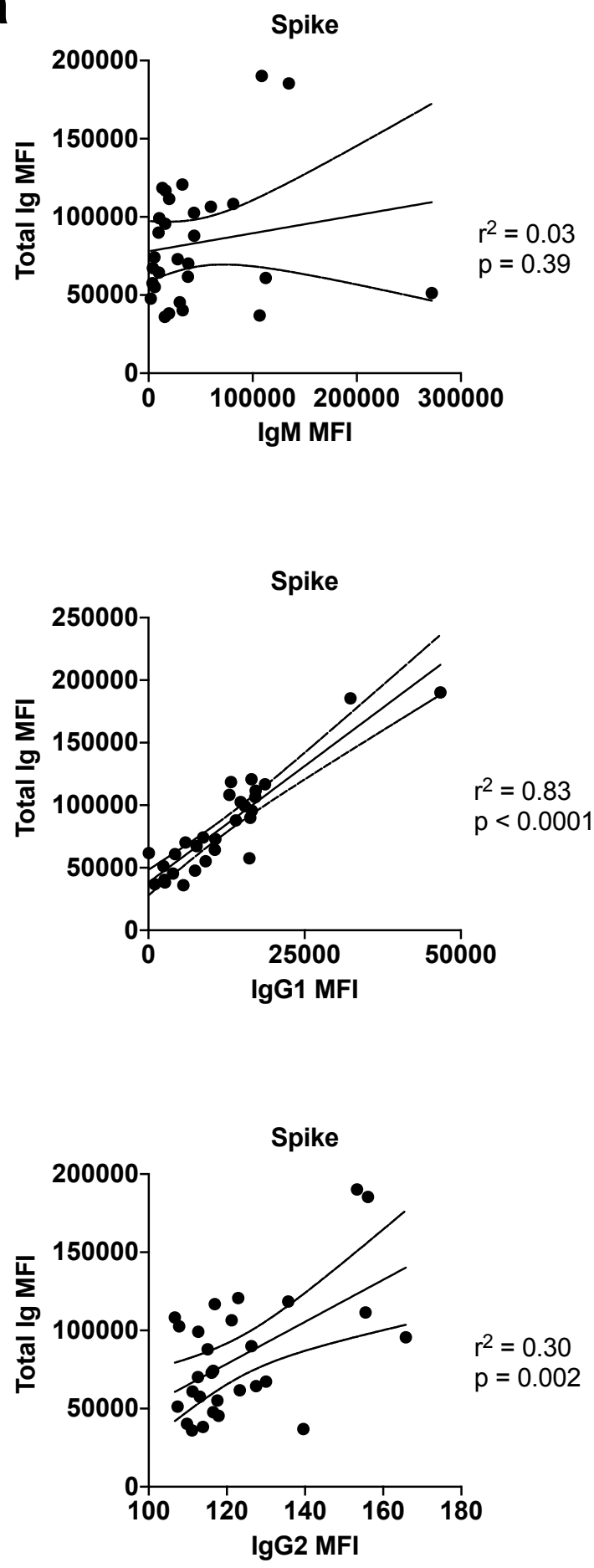

b
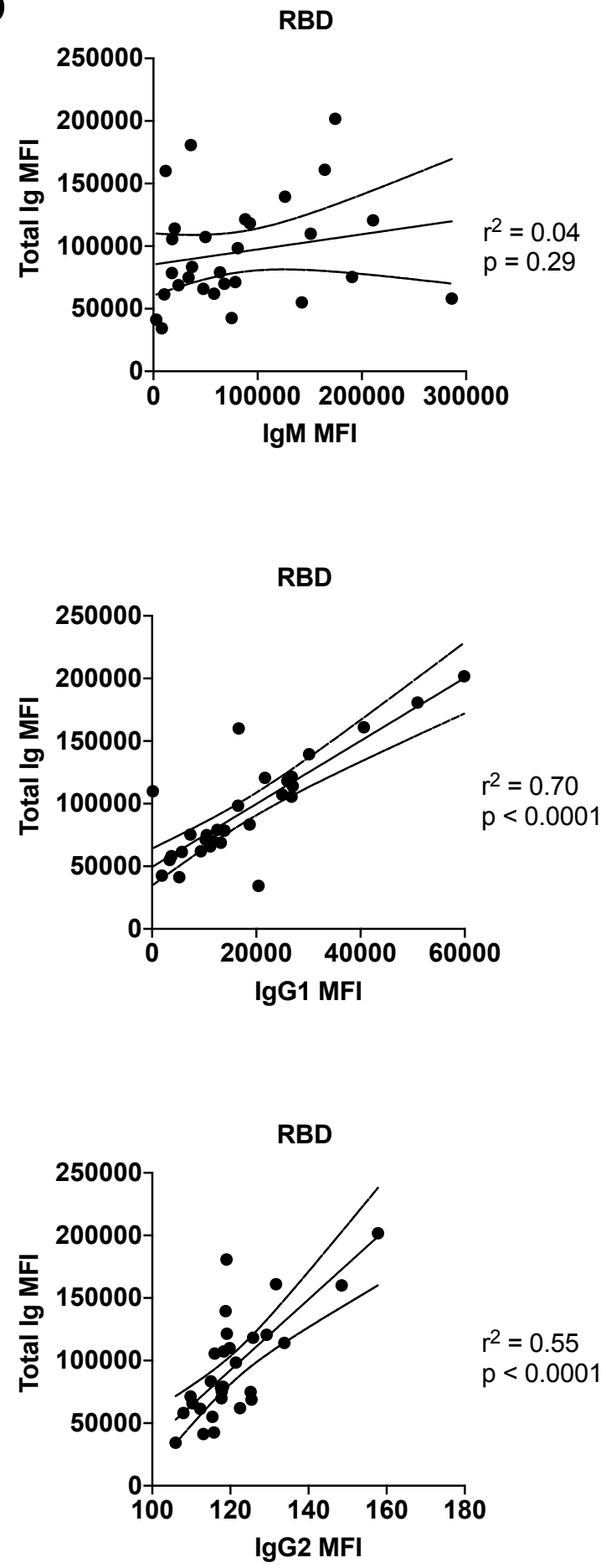

\begin{tabular}{|c|c|c|c|c|}
\hline & \multicolumn{2}{|c|}{ Linear regression spike MFI } & \multicolumn{2}{c|}{ Linear regression RBD MFI } \\
\hline & $\mathbf{r}^{2}$ & $\mathbf{p}$ & $\mathbf{r}^{2}$ & $\mathbf{p}$ \\
\hline Total versus IgG3 & 0.35 & 0.0008 & 0.07 & 0.15 \\
\hline Total versus IgG4 & 0.07 & 0.15 & 0.24 & 0.007 \\
\hline Total versus IgA1 & 0.06 & 0.20 & 0.23 & 0.009 \\
\hline Total versus IgA2 & 0.06 & 0.20 & 0.13 & 0.05 \\
\hline
\end{tabular}


individuals. Simple linear regression of (a) spike-specific or (b) RBD-specific total Ig levels versus IgM, IgG1 or IgG2 levels versus (c) spike-specific and RBD-specific IgG3, IgG4, IgA1, and IgA2 levels from the 29 COVID-19-convalescent individuals from Fig. 1. The dash lines represent $95 \%$ confidence intervals. 
Fig. 4. Neutralization activities are detected in all COVID-19 convalescent individuals.

Neutralization of COV2pp with (a) WT or (b) D614G mutated spike proteins by samples from 28 COVID-19convalescent individuals and 11 COVID-19 uninfected individuals. The neutralizing activity of recombinant soluble RBD (sRBD) is shown as a positive control. Twenty-four hours before infection, 20,000 Vero-CCL81 cells/well were seeded. Virus (82.5 $\mu \mathrm{L} /$ well) was pre-incubated with serially diluted samples $(27.5 \mu \mathrm{L} /$ well, 4 -fold from 1:10 to $1: 40,960)$ for 30 minutes at room temperature. The virus/sample mix was then added to the cells and spinoculated by centrifugation (1250 rpm, 1 hour, room temperature). Six virusonly and six medium-only wells were kept for each plate. After 18 to 22 hours at $37^{\circ} \mathrm{C}$, infection was measured by luciferase activity. sRBD was tested as a positive control at 4-fold dilutions from 100 to $0.02 \mu \mathrm{g} / \mathrm{mL}$. The data are shown as mean percentage of neutralization + SD of triplicates. The extrapolated titration curves were generated using a nonlinear regression model in GraphPad Prism (Inhibitor versus response - variable slope [four parameters], least squares regression). The dotted horizontal lines highlight $50 \%$ neutralization. (c) Spearman correlation between the IC90 titers against COV2pp WT vs. D614G. 


\begin{tabular}{|c|c|c|c|c|c|c|c|c|c|c|c|c|c|c|c|c|c|c|c|c|c|}
\hline & \multirow[t]{2}{*}{ Sex } & \multicolumn{8}{|c|}{ Spike } & \multicolumn{8}{|c|}{ RBD } & \multicolumn{2}{|c|}{ Neutralization } & \multicolumn{2}{|c|}{$\begin{array}{l}\text { Neutralization } \\
\text { D614G mutant }\end{array}$} \\
\hline & & Total Ig & IgM & IgG1 & IgG2 & IgG3 & IgG4 & IgA1 & $\operatorname{IgA2}$ & Total Ig & IgM & IgG1 & IgG2 & IgG3 & IgG4 & IgA1 & IgA2 & $I C_{50}$ & $I C_{90}$ & ${ }^{I} C_{50}$ & $I C_{90}$ \\
\hline P\#5 & unknown & ++ & + & + & - & - & - & ++ & - & + & - & + & - & - & - & + & + & 36.6 & 2.3 & nd & nd \\
\hline P\#6 & unknown & +++ & + & ++ & - & - & + & + & - & ++ & + & + & - & + & - & + & + & 561 & 26 & nd & nd \\
\hline P\#7 & unknown & + & ++ & + & - & - & - & + & - & ++ & ++ & + & - & - & - & + & - & nd & nd & nd & nd \\
\hline P\#8 & unknown & ++ & + & ++ & - & - & + & + & - & + & ++ & + & - & - & - & + & - & 376 & 10 & nd & nd \\
\hline TF\#1 & $\mathbf{F}$ & + & + & + & - & - & - & + & - & ++ & + & ++ & - & - & - & + & - & 419 & 22 & 255 & 29 \\
\hline TF\#2 & $M$ & ++ & + & ++ & - & - & - & + & - & ++ & + & + & - & - & - & + & - & 178 & 12 & 60 & 13 \\
\hline TF\#3 & $M$ & ++ & + & + & - & - & - & + & - & ++ & + & + & - & - & - & + & + & 165 & 20 & 206 & 88 \\
\hline TF\#4 & $\mathbf{F}$ & + & + & + & - & - & - & + & - & ++ & + & + & - & - & - & + & - & 999 & 40 & 329 & 62 \\
\hline TF\#5 & $M$ & ++++ & ++ & ++++ & - & - & - & ++ & - & ++++ & +++ & +++ & - & - & - & ++ & + & 2345 & 516 & 4138 & 730 \\
\hline TF\#6 & $\mathbf{F}$ & ++ & + & + & - & - & - & + & - & ++ & + & ++ & - & + & - & + & - & 977 & 52 & 552 & 100 \\
\hline TF\#7 & $F$ & +++ & + & ++ & - & + & - & ++++ & + & ++++ & + & ++ & - & - & - & ++++ & + & 5789 & 91 & 453 & 81 \\
\hline TF\#8 & $M$ & + & + & + & - & - & - & + & - & ++ & + & + & - & - & - & + & - & 2840 & 142 & 700 & 129 \\
\hline TF\#9 & $F$ & +++ & ++ & ++ & - & - & - & +++ & + & +++ & ++ & ++ & - & + & - & ++ & + & 4044 & 117 & 664 & 123 \\
\hline TF\#10 & $M$ & ++ & + & + & - & - & - & + & - & +++ & + & ++ & - & - & - & + & + & 1060 & 73 & 572 & 75 \\
\hline TF\#11 & $M$ & ++ & ++++ & + & - & - & - & + & - & ++ & ++++ & + & - & - & - & + & - & $>40960$ & 7200 & $>40960$ & 2344 \\
\hline TF\#12 & $\mathbf{F}$ & + & + & + & - & - & - & + & - & ++ & ++ & + & - & - & - & + & - & 286 & 30 & 326 & 54 \\
\hline TF\#13 & $M$ & ++ & ++ & + & - & - & - & +++ & + & ++ & +++ & + & - & - & - & + & + & 1698 & 145 & 1573 & 156 \\
\hline TF\#14 & $M$ & +++ & + & ++ & - & - & - & + & - & ++ & + & + & - & + & - & + & - & 17079 & 201 & 675 & 151 \\
\hline TF\#15 & $M$ & +++ & + & ++ & - & - & - & - & - & +++ & ++ & ++ & - & - & - & - & - & 2006 & 30 & 549 & 68 \\
\hline TF\#16 & $M$ & +++ & + & ++ & - & - & - & + & + & +++ & ++ & ++ & - & - & - & + & + & 1331 & 106 & 1961 & 233 \\
\hline TF\#17 & $M$ & ++ & + & + & - & - & - & + & - & +++ & + & ++ & - & - & - & + & - & 198 & 27 & 186 & 40 \\
\hline TF\#18 & $\mathbf{F}$ & ++ & + & ++ & - & - & - & ++ & - & +++ & + & ++ & - & - & - & + & + & 1122 & 57 & 454 & 64 \\
\hline TF\#19 & $M$ & ++ & + & + & - & - & - & + & - & ++ & + & + & - & - & - & - & - & 326 & 18 & 201 & 32 \\
\hline TF\#20 & $\mathbf{F}$ & ++ & + & ++ & - & - & - & ++ & - & +++ & +++ & ++ & - & + & - & + & + & 1535 & 72 & 471 & 76 \\
\hline TF\#21 & $M$ & ++++ & ++ & +++ & - & + & - & ++ & - & ++++ & +++ & ++++ & - & - & - & + & + & 5376 & 390 & 3231 & 412 \\
\hline TF\#22 & $M$ & ++ & + & ++ & - & - & - & + & - & + & - & ++ & - & - & - & + & + & 623 & 5 & 47 & 12 \\
\hline TF\#23 & unknown & ++ & + & - & - & - & - & ++ & - & +++ & +++ & - & - & - & - & + & - & 3882 & 108 & 564 & 171 \\
\hline TF\#24 & $M$ & + & + & + & - & - & - & ++ & + & ++ & + & + & - & - & + & ++ & + & 814 & 24 & 215 & 71 \\
\hline TF\#25 & $\mathbf{F}$ & +++ & + & ++ & - & - & - & + & - & ++++ & + & ++++ & - & - & - & + & - & 959 & 79 & 605 & 134 \\
\hline
\end{tabular}


Fig. 5. Summary of relative Ig isotype levels and neutralization titers. Table showing sex

(purple, F: female, M: male), relative levels of spike-specific (green) and RBD-specific (blue) Ig isotypes (+: bottom quartile, ++ : second quartile, +++ : third quartile, ++++ : top quartile, -: non-responder) and reciprocal IC50 and IC90 neutralization titers against WT pseudovirus (orange) and D614G pseudovirus (red) of 29 plasma samples from COVID-19 convalescent individuals. nd: not done. 
Fig. 6. IgM and IgG1 contribute most to SARS-CoV-2 neutralization. Simple linear regression of reciprocal IC90 neutralization titers of 27 COVID-19 convalescent individuals versus (a) spike-specific or (b) RBD-specific total Ig, IgM, IgG1 and IgA1 Ab levels. The black dash lines show the $95 \%$ confidence intervals. The dotted vertical red line represents the cut-off (mean of 12 pre-pandemic samples $+3 \mathrm{SD}$ ) for each isotype from Fig. 1. (c) Statistical results of simple linear regression analyses of reciprocal IC90 neutralization titers of 27 COVID-19 convalescent individuals versus spike-specific or RBD-specific Abs levels for IgG2-4 and IgA2. 
Fig. 7. Purified IgM, IgG, and IgA fractions display neutralizing activities against

SARS-CoV-2. (a) Neutralization of COV2pp by five COVID-19-infected individual plasma samples (RP\#1-5) compared to a specimen from a COVID-19 uninfected individual (RN\#1, green filled circles). Plasma samples were tested at 4-fold dilutions from 1:10 to 1:40,960 or 1:20 to $1: 81,920$. Data are shown as the mean percentage of neutralization. The dotted horizontal lines highlight 50\% and 90\% neutralization. (b) Reciprocal IC50 and IC90 neutralization titers of RP\#1-5 plasma samples (c) Neutralization of COV2pp by purified IgM, IgG, and IgA fractions from five COVID-19-infected individuals (RP\#1-5) compared to a control Ig fraction (gray open triangles). IgA was isolated first from plasma samples by mixing 1:2 diluted plasma with peptide $\mathrm{M}$ agarose beads $(600 \mu \mathrm{L} / 28 \mathrm{~mL}$ plasma, InvivoGen \#GEL-PDM) for 1.5 hours at room temperature. After washing beads, IgA was eluted with a pH 2.8 buffer (Thermo Scientific \#21004) and neutralized with pH 9 Tris buffer. The passthrough plasma sample was collected for IgG enrichment using protein $\mathrm{G}$ agarose beads (InvivoGen \#GEL-AGG) and subsequently for IgM isolation using a HiTrap IgM column (G.E. Healthcare \#17-5110-01). An additional purification step was performed using Protein A Plus mini-spin columns to separate $\operatorname{IgG}$ from IgM. The fractions were tested at 4-fold dilutions from 500 to $0.02 \mu \mathrm{g} / \mathrm{mL}$. Data are shown as the mean percentage of neutralization. The dotted horizontal lines highlight 50\% neutralization. (d) IC50 of purified IgM, IgG, and IgA fractions from RP\#1-5. The statistical significance was determined by a two-tailed Mann-Whitney test $\left(*: \mathrm{p}<0.05,{ }^{* *}: \mathrm{p}<0.01\right)$. 